\title{
A INTERVENÇÃO DO ESTADO NA PROPRIEDADE PRIVADA E O PAPEL DO MUNICÍPIO
}

\author{
GustaVo HENRIQUe BAPTISTA ANDRADE ${ }^{1}$
}

Resumo: Centrado na temática da função social da propriedade, o presente trabalho versa sobre o papel do ente federativo municipal no âmbito da intervenção do Estado na propriedade privada, mais especificamente como se dá a atuação do Município nesse campo, em quais hipóteses e sob que fundamentos e limites. A função social da propriedade foi incluída no rol dos direitos fundamentais e também entre os princípios da ordem econômica, permeando todo o texto constitucional, porquanto fundamento e objetivo da República. Está também presente de maneira expressa na política urbana, inaugurando a Constituição de 1988 uma nova concepção da propriedade, não mais atrelada ao indivíduo exclusivamente, mas funcionalizada à justiça social. Além da função social, restrições administrativas ao conteúdo da propriedade formam o conjunto de medidas interventivas que demonstram a especial relevância do papel do Município como executor da política de desenvolvimento urbano.

Palavras-Chave: Propriedade privada; Função social; Intervenção; Município

ABSTRACT: Centered on the theme of the social function of property, the present work deals with the role of the municipality in the scope of the State intervention in private property, more specifically how the Municipality acts in this field, in which hypotheses and on what grounds and limits. The social function of property was included in the list of fundamental rights and also among the principles of the economic order, permeating the entire constitutional text, as the foundation and objective of the Republic. It is also present expressly in urban politics, inaugurating the 1988 Constitution a new conception of property, no longer tied to the individual exclusively, but functionalized to social justice. In addition to the social function, administrative constraints on the content of the

\footnotetext{
${ }^{1}$ Doutor em Direito Civil pela Universidade Federal de Pernambuco - UFPE. Pesquisador visitante do Max-Planck-Institut für Ausländisches und Internationales Privatrecht (MPIPRIV), Hamburgo, Alemanha. Pesquisador do Grupo Constitucionalização das Relações Privadas (CONREP-UFPE). Pesquisador do Grupo Historicidade e Relatividade do Direito Civil (UERJ) Diretor do Instituto Brasileiro de Direito de Família - Seção Pernambuco (IBDFAM-PE). E-mail: gustavo@gustavoandrade.adv.br. ORCID: 0000-0002-9339-0874, (disponível em: https://orcid.org/0000-0002-9339-0874).
} 
property form the set of intervention measures that demonstrate the special relevance of the Municipality's role as executor of urban development policy.

KEYWORDS: Private property; Social function; Intervention; Municipality.

\section{INTRODUÇÃO}

O presente estudo tem por objeto a análise acerca da atuação do Município no campo da intervenção do Estado na propriedade privada, trazendo como problematização o apontamento das hipóteses de limitação ao exercício do direito de propriedade pelo referido ente federativo.

Diferentemente do que ocorreu na Europa, onde o conceito moderno de propriedade privada foi estruturado a partir das relações feudais do medievo e amadurecido com a passagem para o Estado liberal pós-revolucionário do século XVIII, no Brasil a concepção do instituto experimentou desde o descobrimento uma forte ligação com o direito administrativo. Isto porque, com a colonização, as terras descobertas passaram a pertencer à Coroa portuguesa, que mantinha os particulares em uma relação de natureza jurídico-administrativa, a exemplo das sesmarias, distribuição de terras destinadas à produção agrícola (VARELA; LUDWIG, 2002, p. 749).

A propriedade privada tomou forma a partir da propriedade pública, cuja transmissão se dava pela apropriação pelos particulares através de três formas fundamentais, quais sejam, a usucapião, as cartas de sesmarias e a posse sobre terras devolutas.

De fato, a passagem do modelo feudal para a propriedade privada dos códigos oitocentistas não encontra correspondente na experiência brasileira. O Brasil não conheceu a complexa hierarquia dominial da Idade Média. Independentemente dessa contingência história, o modelo unitário e absoluto da propriedade moderna aporta tardiamente no Brasil com o advento do Código de 1916, já no século XX.

Não que o direito de propriedade brasileiro deixe de apresentar as mesmas origens do direito continental do sistema romano-germânico, até porque vigiam no país colonial as ordenações do reino de Portugal, cuja base foi o direito civil da península ibérica oriundo do Código Visigótico, mesmo depois da invasão e domínio dos árabes (ANDRADE, 2019, p. 45). A questão é que no Brasil a propriedade foi individualizada através da outorga direta do Estado e, somente depois, pelas relações jurídicas de direito patrimonial privado.

No Brasil, o direito de propriedade figura em todas as Constituições. E já em 1934, a Constituição que inaugurou o Estado social brasileiro apresentou pela primeira vez na história um título sob a rubrica da ordem econômica e social. Esta 
passa a ser organizada conforme os princípios da justiça e as necessidades da vida nacional, de modo a possibilitar a todos existência digna, com forte intervenção do Estado. Aqui se encontra o germe da função social da propriedade no direito brasileiro².

A funcionalização da estrutura referente ao conceito jurídico de propriedade é um processo histórico que tem sua consolidação nas constituições do século $X X$, com a transição do Estado liberal para o social. Atualmente, o regime jurídico da propriedade não mais se subordina exclusivamente ao direito civil, estando delineado também na Constituição da República.

A Constituição brasileira de 1988 garantiu o direito de propriedade (art. 5ㅜ XXII), não porém de maneira absoluta, já que além das limitações históricas presentes nas demais Cartas, a exemplo da desapropriação (art. $5^{\circ}$, XXIV) e do uso da propriedade privada pelo Estado no caso de iminente perigo público (art. $5^{\circ}$, $\mathrm{XXV}$ ), entre outras de ordem legal, como as urbanísticas e ambientais, condicionou de forma expressa o seu exercício a uma função social (art. 5ํㅜ, XXIII).

Não bastasse a inclusão da função social da propriedade no rol dos direitos fundamentais, o que por si só justificaria o fato de que toda forma de propriedade estaria vinculada a esse princípio, quis o constituinte que a função social figurasse também entre os princípios da ordem econômica (art. 170, III).

A função social, em verdade, permeia todo o texto constitucional, porquanto é fundamento e objetivo da República. Além dos dispositivos acima mencionados, está presente também de maneira expressa na política urbana (art. 182, caput), na política agrária e fundiária e na reforma agrária (arts. 184 e 186, CR). A Constituição de 1988 inaugura dessa maneira uma nova concepção da propriedade, não mais atrelada ao indivíduo exclusivamente, mas funcionalizada à justiça social ${ }^{3}$.

2 Art. 115. A ordem econômica deve ser organizada conforme os princípios da Justiça e as necessidades da vida nacional, de modo que possibilite a todos existência digna. Dentro desses limites, é garantida a liberdade econômica. Parágrafo único. Os Poderes Públicos verificarão, periodicamente, o padrão de vida nas várias regiões do país.

${ }^{3}$ Não há que se confundir função social com interesse social, o que não é incomum. Interesse social, como a própria expressão aponta, está ligado ao interesse de um grupo, traduzido em um conjunto de condições limitativas que, de um modo ou de outro, condicionam e restringem o uso e gozo de bens públicos e privados. Interesse social é um conceito afeto ao direito administrativo, já que se materializa por intermédio de ações do Estado, como o poder de polícia ou a expropriação de bens de particulares, entre outras. A função social é um princípio constitucional de forte impacto nas relações privadas, no tráfego jurídico, na circulação de bens, na ordem econômica enfim. Embora expressamente vinculada à propriedade, como é de ver-se do próprio texto constitucional (arts. $5^{\circ}$, XXIII e 170, III), trata-se do condicionamento das situações jurídicas de direito privado ao projeto constitucional do Estado social brasileiro, que tem por fundamento, entre outros, a dignidade da pessoa humana e os valores sociais da livre-iniciativa na busca de uma sociedade livre, justa e solidária (art. $3^{\circ}$, I), baseada numa ordem econômica que tem por fim assegurar a todos existência digna, na conformidade da justiça social (art. 170, caput). De 
Dada a opção explícita da ordem constitucional brasileira pelo Estado social, o que se consubstancia não somente em seus fundamentos (art. $1^{\circ}$ ), objetivos (art. $3^{\circ}$ ) e outros direitos e garantias que figuram no texto da Constituição, mas em especial por ter a ordem econômica e financeira sido alicerçada nos ditames da justiça social, o que autoriza o poder público a intervir no sentido de assegurar os princípios estampados no art. 170, de grande importância é o tratamento jurídico dispensado à propriedade.

Além da função social, limitações administrativas ao conteúdo da propriedade formam o conjunto de medidas interventivas, demonstrando-se de especial relevância o papel do Município como executor da política de desenvolvimento urbano, não à toa insculpido no Capítulo II do Título relativo à ordem econômica.

O contexto acima apresentado já permite extrair algumas premissas que servirão como orientação para o restante das ideias que serão desenvolvidas no presente trabalho: (i) os direitos subjetivos privados não se confinam no âmbito individual de seus titulares, projetando-se no ambiente social, numa simbiose que contribui decisivamente para a conformação de seus significados; (ii) o lugar e o tempo são elementos determinantes na compreensão do sentido de função social, pois o intérprete deve levar em conta os valores sociais dominantes na época e no espaço da concretização do conteúdo do referido princípio nas relações entre particulares, tanto sob a perspectiva interna (entre os próprios figurantes), quanto sob a perspectiva externa (entre os figurantes e o corpo social).

E no sentido de melhor contribuir com uma compreensão mais precisa acerca da intervenção do Estado na propriedade, ainda que, no caso deste texto, sob o prisma do ente federativo municipal, duas questões distintas, porém interligadas devem ser exploradas: a função social da propriedade e as limitações ao exercício do direito de propriedade que decorrem de ato do poder público, porém sem disposição constitucional específica. Nesse aspecto, instituto jurídico necessita ser analisado, dada a sua nítida intersecção com o princípio da função social. Trata-se do interesse público, conceito jurídico indeterminado que, embora não versado de maneira explícita como princípio constitucional, tem sua prevalência sobre o interesse privado (do particular), reconhecida como princípio implícito que rege a organização do Estado brasileiro e de seus Poderes, o que se conclui através da interpretação das normas do sistema, em especial os arts. 19, 37, 57, 66, 93, 95, 114 e 128, onde expressamente mencionado o referido conceito.

Em verdade, no Estado democrático de direito, o interesse público se revela através da observância, pelos poderes constituídos, dos direitos, garantias e princípios consagrados na Constituição e no sistema jurídico como um todo. E assim, toda atividade administrativa do Estado deve ser direcionada à concretude

uma maneira geral, traduz-se pela funcionalização das estruturas de direito privado à justiça social, Cf. Silva (2012, p. 272). 
desses mesmos direitos, em cujo ponto de partida deve figurar sempre o princípio da dignidade da pessoa humana (ISMAIL FILHO, 2016).

Com o desenvolvimento do tema, procurar-se-á demonstrar que as limitações administrativas são aspectos extrínsecos ao direito de propriedade, originários do poder de polícia do Estado. Já a função social é conteúdo intrínseco ao direito de propriedade, uma vez que este somente poderá ser exercido se atendida essa função por determinação constitucional.

O artigo está dividido em dois blocos temáticos, onde estão distribuídos cinco itens. A primeira parte, que engloba os dois primeiros itens, trará um panorama sobre o direito de propriedade à luz da legalidade constitucional. O segundo bloco abordará em seus três itens, sob a perspectiva da intervenção do Estado na propriedade, o efetivo papel do Município nessa relação jurídica.

\section{Direito Privado e Constituição}

Sem o aprofundamento necessário para um trabalho em cujo contexto a relação entre direito privado e Constituição tem por condão situar o leitor na contingencialidade imposta em um artigo que explora um instituto jurídico, onde a historicidade também assume importante papel, servirá o presente item para oferecer um panorama acerca do direito de propriedade em sua acepção contemporânea, sob a eficácia da legalidade constitucional.

A doutrina da constitucionalização das relações privadas vem contribuindo enormemente para a interação do direito privado com as mudanças sociais. A interpretação das normas de direito privado de acordo com as regras e princípios insculpidos na Constituição, reforça e chancela o projeto constitucional que tem por fundamentos, entre outros, a dignidade da pessoa humana e os valores sociais do trabalho e da livre iniciativa, e possibilita o alcance dos objetivos nele estabelecidos, dentre os quais a construção de uma sociedade pautada na liberdade, na justiça e na solidariedade, onde a pobreza seja erradicada e as desigualdades sociais reduzidas.

Críticas não são incomuns e questionamentos surgem a partir de uma ideia equivocada de que os adeptos da constitucionalização creem que o direito civil nasceu ou renasceu com a Constituição de 1988. Não há em absoluto essa crença. Inexiste menosprezo ao caráter milenar do direito civil e seus mais caros institutos, pelo contrário. O constitucionalismo do século XX que se ergue sobre os pilares do Estado social, institui uma série de vínculos e limites a todos os poderes públicos, deixando a vocação programática das Constituições para estabelecer força normativa capaz de empreender a concretização dos direitos fundamentais, dos direitos sociais e da ordem econômica voltada para a justiça social, assim como outros ali inscritos.

As duas últimas fases do Estado moderno, que datam de aproximadamente duzentos e cinquenta anos, se iniciam com a passagem do absolutismo para o 
Estado liberal, continuando com o advento do Estado social. São ricos momentos da história da humanidade e que trouxeram inigualável contribuição para o direito.

A opção pelo Estado social no Brasil, já na primeira metade do século XX, aliada à promulgação de uma constituição que vem restaurar a democracia no país após mais de duas décadas de ditadura militar, pode acarretar uma primeira impressão de que se defende rupturas capazes de reduzir a importância do direito privado, relegando-o a um adendo, um complemento do direito constitucional. Não é o que de fato ocorre.

Convém salientar sempre que, quando se fala em constitucionalização do direito privado, não se quer afirmar que as normas do direito civil ou do consumidor, por exemplo, necessitam estar encravadas no texto constitucional. Pelo contrário, as normas infraconstitucionais vão buscar na Constituição seu fundamento de validade, ainda que valores fundamentais do direito privado tenham sido absorvidos pela Carta de 1988.

O que importa também destacar e dá a tônica da Constitucionalização é o abandono pela Constituição dos efeitos simbólicos das normas programáticas, voltando-se para a plena eficácia dos valores escolhidos para o fundamento da organização social, convertidos em regras e princípios constitucionais.

Referindo-se ao direito civil, de onde germina o direito do consumidor, Paulo Lôbo (2019, p. 52) define a constitucionalização como o processo de elevação ao plano constitucional dos princípios fundamentais do direito privado, os quais passam a condicionar a observância da legislação infraconstitucional. A doutrina da constitucionalização do direito civil tem seu fundamento em ao menos três pressupostos teóricos, quais sejam, a força normativa da Constituição, que perde sua vocação de conjunto de normas meramente programáticas, a unidade e complexidade do ordenamento jurídico voltado aos princípios e valores constitucionais, e a renovação da teoria da interpretação considerando os valores e fins a serem aplicados (LÔBO, 2019. p. 53). O ordenamento jurídico de cunho civil-constitucional, além de estruturar os institutos fundantes do direito privado, não se limita a seguir as diretivas constitucionais como se fossem meros conselhos, mas as concretiza na busca permanente de uma resposta que almeja conhecer: "para que e a quem serve o direito?" (FACHIN, 2018, p. 17). Não se deve deixar de registrar que, em seu percurso, o "processo" de constitucionalização do direito privado é antecedido e acompanhado pela intervenção do legislador infraconstitucional em diversas disciplinas.

$\mathrm{Na}$ esteira do ensinamento de Lôbo (2009, p. 41), é possível afirmar seguramente que o sistema legislativo do direito privado brasileiro é formado pelas normas constitucionais, em torno das quais orbitam o Código Civil, a legislação civil especial e os microssistemas jurídicos, a exemplo do Código de Defesa do Consumidor, no que concerne ao direito material. Importante ter em mente que esses universos estão interligados. Não há rupturas, já que a legislação 
infraconstitucional de direito privado é aplicada de maneira a que o núcleo normativo da Constituição nessa matéria se expresse com a energia necessária (LÔBO, 2009, p. 43). Não há desapreço pelas raízes históricas do direito civil. O que se questiona é o papel atual do Código Civil, que há muito deixou de deter exclusividade na regulação das relações patrimoniais privadas e não mais representa a "Constituição do direito privado", como sói acontecer até o advento das constituições que inauguraram o Estado social. Não há fragmentação do sistema. Ainda que se reconheça a existência de universos legislativos setoriais, busca-se a unidade do sistema através do deslocamento do ponto de referência antes localizado no Código Civil para a tábua axiológica da Constituição:

O percurso evolutivo dos institutos do direito privado é a demonstração eloquente desse processo. A exagerada atenção do vetusto Código Comercial para com o comerciante dá lugar à ênfase central em relação aos atos de comércio e à empresa. A tônica excessiva do Código Civil em torno do sujeito de direito cede a atenção do legislador especial para com as atividades, seus riscos e impacto social, e para a forma de utilização dos bens disponíveis, de maneira a assegurar resultados sociais pretendidos pelo Estado (TEPEDINO, 2004, p. 07).

A Escola italiana de direito civil constitucional, que tem como um dos maiores expoentes o jurista Pietro Perlingieri, surge justamente da necessidade de adaptação das leis e códigos que constituíam o ordenamento jurídico daquele país - em sua maioria expressão de valores que buscavam fazer do produtivismo estimulado pelo Estado sua maior característica - aos limites que a Constituição passou a impor quanto ao respeito aos direitos fundamentais da pessoa humana. Necessário apontar que a Constituição italiana entrou em vigor em 1948, portanto, após o final da Segunda Guerra Mundial, e passou a conviver com um Código Civil, editado em 1942 ainda sob os auspícios do fascismo. Assim nasceu a importância da releitura do Código Civil sob a ótica constitucional, na qual o produtivismo encontrou os mencionados limites da valorização da pessoa humana. Impôs-se aos juristas a obrigação de considerar a prioridade hierárquica das normas constitucionais quando necessário resolver um caso concreto e a consciência de que o ordenamento é unitário. Isto possibilitou que a solução para cada controvérsia deixasse de ser encontrada exclusivamente no artigo de lei que parecia contempla-la, mas à luz do inteiro ordenamento e, em especial, de seus princípios fundamentais (PERLINGIERI, 2002, p. 05). 


\section{A PROPRIEDADE PRIVADA NO ORDENAMENTO BRASILEIRO}

A Constituição brasileira de 1988, talvez em razão de uma organização sistemática, garante o direito de propriedade no inciso XXII do seu art. $5^{\circ}$, iniciando uma sequência de dez dispositivos a ele correlatos. Na verdade, diversos são os artigos da Constituição que figuram sob o espectro do direito de propriedade, destacando-se, por óbvio, dados os próprios fundamentos e objetivos da República, o dispositivo que condiciona o exercício do direito de propriedade ao atendimento de sua função social (art. $5^{\circ}, \mathrm{XXIII).}$

José Afonso da Silva cita as normas constitucionais que considera interferir na propriedade mediante provisões especiais, entre as quais, além dos incisos XXII a XXX do art. $5^{\circ}$, os dispositivos referentes à desapropriação e usucapião, e os incisos II e III do art. 170, estes responsáveis por colocar a propriedade e a sua função social entre os pilares da ordem econômica do Estado brasileiro, o que vem a relativizar o seu significado, em especial por estarem os princípios que regem a ordem econômica voltados à realização de um fim, qual seja, assegurar existência digna a todos, conforme os ditames da justiça social (SILVA, 2012, p. 271). Percebe ainda o mesmo autor que a função social "é elemento da estrutura e do regime jurídico da propriedade; é, pois, princípio ordenador da propriedade privada; incide no conteúdo do direito de propriedade; impõe-lhe novo conceito". A complexa situação jurídica subjetiva em questão não deve ser compreendida de modo fragmentado, mas como uma instituição de direito civil no ambiente que a disciplina constitucional lhe reserva (SILVA, 2012, p. 273). Em outras palavras, como defendido pela metodologia civil-constitucional, as normas de direito civil sobre a propriedade devem ser compreendidas e interpretadas em conformidade com o texto constitucional.

Para alargar a concepção da função social em um aspecto que se relaciona de maneira estreita com o presente artigo, contribui Stefano Rodotà (2013, p. 330) com o entendimento de que o princípio da função social, mais do que um critério formal legitimador de medidas legislativas que governam a situação dos proprietários privados, opera também como um critério necessário para a interpretação desse material legislativo, por intermédio de métodos segundo os quais dito princípio se manifesta de imediato e é concretamente utilizável como uma ferramenta de controle das atividades desses proprietários. De onde é possível perceber que, embora as intervenções e limitações levadas à efeito pelo Estado na propriedade privada sejam afetas ao direito administrativo, em decorrência do interesse social - que com a função social não se confunde - não se pode deixar de admitir que, como direito fundamental e princípio norteador da ordem econômica, a função social da propriedade, para além da situação jurídica proprietária, irradia sobre o sistema como um todo, influenciando também as políticas públicas a serem desenvolvidas pelos entes estatais, entre os quais se 
destaca o Município por lhe caber a política urbana e demais medidas que compõem a administração de seu território.

Com o propósito de aclarar e tornar mais precisa a compreensão de certos institutos, não é incomum alguns juristas fazerem uso do raciocínio lógico. $\mathrm{Na}$ busca por tal precisão em uma categoria abstrata como se mostra a princípio a função social da propriedade, onde os excessos teóricos se mostram recorrentes e dificultam demasiadamente a compreensão, Luciano de Camargo Penteado faz uso da teoria matemática dos conjuntos, na qual a noção de relação e função são centrais, como também ocorre com o direito privado. De acordo com o referido autor, na teoria matemática da relação entre conjuntos, há função quando existe um especial tipo de relação, segundo a qual há referência do elemento de um conjunto a um outro elemento pertencente a outro conjunto, de forma única para cada elemento considerado:

Os conjuntos matemáticos são reuniões de elementos. Quando existe relação, os elementos de um conjunto passam a estar referidos, e merecem ser apontados, de alguma forma e segundo algum critério, aos elementos de outro conjunto. Relação é referência do elemento a um outro. Consiste em um tipo de projeção para fora de si. Não é substancialmente diverso do conceito em filosofia. Quando a relação for de um tipo determinado, qual seja, aquele em que cada elemento do conjunto inicial, convencionalmente denominado conjunto de partida, possui referência a apenas um elemento do conjunto de chegada e todos têm alguma relação com elementos do conjunto imagem, há função. A primeira condição necessária é ter referência de todos a algum elemento, mas não é suficiente. É necessária simultaneamente, a referência a um único elemento da imagem, isto é, não há elementos do conjunto de partida em relação com mais de um (elemento) do conjunto de chegada. Satisfeitas estas duas condições, teremos em matemática uma função.

Em direito, apontar para a função de certos institutos ou situações jurídicas nada mais seria do que afirmar que a sua configuração normativa apresenta uma destinação extrínseca a ser observada e obedecida, ainda que configure de modo diverso a própria situação jurídica a partir de dentro. Em outras palavras, os elementos do direito não são autossuficientes sempre, podendo desempenhar papéis que o próprio sistema jurídico, o sistema econômico, ou ainda o social desenham para eles. Na hipótese de haver um desvio destes objetivos, pode haver diferentes mecanismos de correção de rota ou objetivo, numa tentativa de retorno ao caminho traçado (PENTEADO, 2014, p. 201). 
A propriedade, então, quer como elemento do conjunto formado pelas diversas situações jurídicas subjetivas típicas, quer contemplando ela própria o conjunto das diferentes situações jurídicas reais (conjunto inicial ou de partida), se refere ao interesse social (conjunto de chegada) e a ele é direcionado. De acordo com o sistema jurídico brasileiro, a situação proprietária apresenta uma função e esta é social, de onde se conclui que a propriedade se relaciona com um fim externo a ela, que também é social (interesse social), o que possibilita também depreender que o ordenamento jurídico, reconhecendo a "insuficiência da atribuição do domínio para a regularidade e valoração da situação jurídica proprietária", encontra a "necessidade de dar-lhe outra destinação, escolhida esta pela comunidade sociopolítica, a justificar, dialeticamente, a sua proteção" (PENTEADO, 2014, p. 201).

Importante frisar que, embora a relação (referência de um elemento a outro) se consubstancie em uma projeção para fora de si, a função (social) conforma o elemento propriedade a partir de dentro, desenhando-a de outra forma, conforme a precisa conclusão do mesmo autor:

Dizer que existe a função social da propriedade significa dizer que o direito real deve ser exercido no interesse individual, sim, mas que este deve coincidir, ou ao menos se direcionar, apresentar alguma relação com o interesse social, em uma relação de concorrência conjuntiva, de coincidência, de equilíbrio sistêmico, sob pena de haver perturbações na função (PENTEADO, 2014, p. 201).

Ainda que elemento intrínseco ao conteúdo do direito de propriedade no ordenamento jurídico brasileiro, a função social, por se projetar para o alcance do interesse social, se desenvolve no plano consequencial, com seus efeitos práticos específicos. Esta forma de pensar facilita sobremaneira a interpretação e aplicação das normas do sistema como um todo e tende a afastar os apriorismos ideológicos e valorizar o dado normativo.

O Código Civil, por sua vez, reforça essa ideia no parágrafo único do seu art. 2035 ao estabelecer que nenhuma convenção prevalecerá na hipótese de contrariedade a preceitos de ordem pública, como os que o próprio Código prescreve para assegurar a função social da propriedade.

A utilização do princípio da função social se consubstancia em poderosa ferramenta de que dispõe o Poder Judiciário para concretizar sua missão de controle do exercício das mais diversas posições jurídicas, o que será densificado com os elementos do caso concreto que servirão de critério de aproximação da justiça substancial. É papel da doutrina e dos operadores jurídicos em geral não se 
limitarem à repetição de fórmulas prontas e acabadas sobre o tema e investigá-lo sem perder de vista a pauta dos valores consagrados no texto da Constituição da República.

E à lei cabe estabelecer as hipóteses em que atos administrativos e também os de natureza privada terão o condão de interferir e limitar o direito de propriedade. Assim, tanto a atividade administrativa, por intermédio de instrumentos urbanísticos e outros atos administrativos, quanto a negocial não encontrarão limites fora daqueles impostos pela reserva legal, o que assegura o reconhecimento e a garantia do direito de propriedade, assim como de sua função social (PERLINGIERI, 2002, p. 229).

\section{O MUNICÍPIO NA ORGANIZAÇÃO DO ESTADO BRASILEIRO}

Uma grande inovação introduzida pelo ordenamento jurídico inaugurado com a Constituição de 1988 foi o enquadramento do Município como unidade institucional que compõe a forma federativa que organiza o Estado brasileiro. Mais do que isso, a organização político-administrativa da República passou a contar com uma terceira esfera de autonomia, onde se inserem o Município e o Distrito Federal, restando alterada a tradição do federalismo brasileiro (BONAVIDES, 2004, p. 345).

Embora parte da doutrina constitucionalista nacional teça críticas à inserção do Município como unidade componente da federação, que historicamente sempre foi constituída apenas pela União e pelos Estados, não titularizando o Município sequer representação no Congresso Nacional, os arts. $1^{\circ}$ e 18 da Constituição, além do art. 29 e daqueles que versam sobre as competências dos entes federativos, não apenas outorgaram ao Município a condição de ente federativo mas também destacada posição no que diz respeito às competências legislativas e administrativas, em especial em matéria urbanística (TOLENTINO; THIBAU, 2015, p. 24).

No que concerne a essa repartição de competências, dada a complexidade que o constituinte atribuiu ao tema em face de uma regulação descentralizada e híbrida, tentar-se-á demonstrar um sucinto panorama que possibilite ao leitor a compreensão da aludida distribuição, sem o aprofundamento de um estudo específico sobre a temática.

A Constituição brasileira optou por fazer a distribuição da competência dos entes federativos segundo o critério da predominância do interesse, competindo à União versar sobre temas de interesse nacional (arts. 21 e 22), aos Municípios sobre assuntos de interesse local (art. 30) e aos Estados sobre temas regionais, de forma residual (art. 25), sendo atribuídas ao Distrito Federal as mesmas competências dos Estados e Municípios.

${ }^{4}$ Ver por todos, Silva (1996). 
Além do critério da predominância do interesse, a Carta de 1988 estabeleceu competência concorrente e comum entre os entes federativos, partilhando as competências legislativa e administrativa entre os mesmos, em um modelo descentralizado mas que dificulta por vezes a delimitação do campo de atuação da União, dos Estados, dos Municípios e do Distrito Federal, a evitar a invasão de competências entre um e outro ente.

O Município, de tal forma, passa a gozar de inquestionável autonomia, alcançando no dizer de Paulo Bonavides, "uma dignidade federativa jamais lograda no direito positivo das Constituições antecedentes" (BONAVIDES, 2004, p. 345).

Em matéria urbanística, não obstante a competência da União para a elaboração e execução de planos nacionais e regionais de ordenação do território e de desenvolvimento econômico e social (art. 21, IX, CR), planejamento e promoção da defesa permanente contra as calamidades públicas (art. 21, XVIII, CR) e instituição de diretrizes para o desenvolvimento urbano (art. 21, XX, CR), além de outras de natureza legislativa (art. 22), somadas à competência comum das unidades federativas, prevista no art. 23 e da concorrente insculpida no art. 24, a Constituição confere também aos Estados membros competência legislativa privativa para, através de lei complementar, instituir regiões metropolitanas, aglomerações urbanas e microrregiões (art. 25, § $3^{\circ}, C R$ ).

São os Municípios, no entanto, que possuem a maior competência em matéria urbanística, seja administrativa ou legislativa, o que acontece dada a predominância dos assuntos de interesse local na competência municipal, o que está explicitado no inciso I do art. 30. Mas não só isto. A Carta de 1988, através do art. 182, conferiu ao Poder Público municipal a execução da política de desenvolvimento urbano, conforme diretrizes gerais fixadas em lei, com o objetivo de ordenar o pleno desenvolvimento das funções sociais da cidade e garantir o bem-estar dos seus habitantes. O mesmo art. 182 estabeleceu o plano diretor como instrumento básico da política de desenvolvimento e de expansão urbana $\left(\S 1^{\circ}\right)$, assim como condicionou o cumprimento da função social da propriedade urbana ao atendimento das exigências fundamentais de ordenação da cidade tal como expressas no aludido instrumento $\left(\S 2^{\circ}\right)$, e prescreveu sanções ao proprietário do solo urbano não edificado, subutilizado ou não utilizado que não promova o seu adequado aproveitamento $\left(\S 4^{\circ}\right)$. A lei a que se refere o caput do art. 182 veio a ser promulgada em 2001. Trata-se do Estatuto da Cidade (Lei ${ }^{\circ}$ 10.257, de 10 de julho de 2001).

\section{A INTERVENÇÃO DO ESTADO NA PROPRIEDADE}

As restrições ao uso da propriedade sempre existiram no constitucionalismo brasileiro e estiveram presentes nas mais diversas feições também na legislação infraconstitucional, desde o poder de polícia ao uso da propriedade particular em 
caso de iminente perigo público (art. $5^{\circ}, \mathrm{XXV}, \mathrm{CR}$ ), à invasão do domicílio nas hipóteses previstas no inciso XI do art. $5^{\circ}$ da Constituição da República e em muitas outras situações, incluindo a mais grave de todas que é a expropriação de bens (art. 5०, XXIV; art. 182, $\S 4^{\circ}$; art. 184; e 243, CR). No panorama contemporâneo, entretanto, com a superação de que a antiga propriedade privada atendia aos interesses exclusivos do proprietário e a adoção, pelo ordenamento, da função social da propriedade, esta tem sua definição delineada também a partir de centros de interesse extraproprietários, que devem ser regulados conforme os preceitos constitucionais e a concreta relação jurídica de propriedade, refutando-se as convicções apriorísticas de ordem ideológica e privilegiando-se o dado normativo (TEPEDINO, 2013, p. 267).

As estruturas jurídicas que conformam as intervenções na propriedade privada, além das normas constitucionais mencionadas, figuram igualmente no Código Civil e, no âmbito do direito público, em um cabedal de leis esparsas, que vão desde a legislação federal, dada a competência da União para legislar sobre direito de propriedade, até as chamadas "posturas municipais", as quais representam um conglomerado de normas jurídicas aptas a regular as condutas dos munícipes quanto aos usos e atividades inerentes aos bens e espaços urbanos, padrões de higiene e salubridade públicas, controle e fiscalização de certas atividades profissionais, além das autorizações para construções no território do Município, entre outras licenças.

Acerca dessas intervenções, Orlando Gomes explica que, a depender da fonte de tais limitações, o proprietário pode ser atingido em toda a extensão do seu domínio ou em algumas de suas faculdades, contra ou não a sua vontade, e no interesse da coletividade, de seu próprio ou no de terceiro, destacando-se as que se inspiram no critério da predominância do interesse público e que vem permitindo a consolidação e expansão da política de intervenção do Estado na propriedade privada (GOMES, 1988, p. 111).

Embora a função social da propriedade, como princípio vetor da situação proprietária atual, se sobreponha e influencie não somente as previsões constitucionais de intervenção mas toda a gama de limitações a que se submete o proprietário, estas não compõem o conteúdo da propriedade como ocorre com a função social; são aspectos externos que se impõem coativamente ao proprietário com fundamento no interesse público, social ou coletivo, considerados em razão da necessidade de coexistência pacífica. De maneira geral, como dito acima, a intervenção praticada pelo Estado está expressa em leis especiais e regulamentos, e pertencem ao campo do direito administrativo.

A limitação é um conceito normativo, já que exige do ordenamento jurídico um elemento que conforme uma situação subjetiva. A rigor, todo direito deve ser exercido de maneira correta, representando o contrário, ou seja, o seu exercício de maneira incorreta, uma limitação. Exemplo paradigmático é o abuso do direito de propriedade, praticado por aquele que ultrapassa o limite do uso normal da 
propriedade, limitação a todos imposta. A atuação do titular do direito fora dos limites da situação jurídica consiste em ato ilícito (art. 187, CC)5.

As limitações mais gerais se encontram insculpidas na Constituição da República. No Código Civil, é o art. 1228 que apresenta o conceito do direito de propriedade e, ao mesmo tempo, dispõe acerca de suas principais limitações. Ao direito administrativo pertencem as intervenções levadas a efeito pelo Estado.

Referenciando a doutrina do jurista português Menezes de Cordeiro, Luciano de Camargo Penteado aponta o princípio da boa-fé também como relevante limite, de forte conteúdo ético, para as situações jurídicas proprietárias:

Ao lado da função social da propriedade, exerce importante papel sobre a propriedade, como critério de estabelecimento de limitações, o princípio da boa-fé. Este, nada obstante a pontuação para negócios jurídicos, é princípio que opera para quaisquer situações jurídicas, ainda que não negociais, sob o mesmo fundamento normativo (CC 113). Nada obstante o fato de ela ter sua atuação predominante sob o prisma subjetivo, em matéria de direito das coisas, está constantemente limitando, especialmente o poder de disposição, determinando imputações dominiais definitivas de acordo com os seus critérios nas hipóteses de acessão, principalmente na modalidade de plantações e construções, benfeitorias, nas presunções que decorrem do registro e, também para a tradição em situação de propriedade aparente (PENTEADO, 2014, p. 271).

A intervenção do Estado na propriedade privada pode se dar, então, através das limitações de ordem administrativa e até com a própria supressão do direito de propriedade, como no caso das desapropriações.

As limitações de direito administrativo podem consistir em obrigações positivas (fazer) e negativas (não fazer), e apresentar natureza ou finalidade de ordem cultural, de segurança, de circulação de pessoas, ambiental, entre outras. Como igualmente mencionado anteriormente, os poderes da Administração pública que podem vir a atingir a propriedade privada devem derivar diretamente de texto de lei, obedecer ao princípio do devido processo legal, e sujeitar o responsável à indenização devida pelo prejuízo infligido ao bem, se for o caso, e à imputação de responsabilidade no caso de eventual prática de ato ilícito (art. 37, $\S 6^{\circ}, \mathrm{CR}$ ).

O Estado pode intervir na propriedade privada de maneira restritiva, quando impõe ao particular restrições e condicionamentos ao exercício do direito de

${ }^{5}$ Cf. Penteado (2014, p. 263). 
propriedade, como acontece com a servidão administrativa, a requisição, a ocupação temporária, as limitações administrativas propriamente ditas e o tombamento; e de maneira supressiva, quando retira do titular não somente o exercício mas o próprio direito de propriedade, como acontece na desapropriação.

A servidão administrativa se assemelha ao direito real de servidão do direito privado (arts. 1378 e ss, CC), consubstanciando-se em uma prerrogativa de gozo ou fruição por parte da Administração pública para aproveitamento da utilidade do bem, a que o particular é obrigado a tolerar. Caso seja instituída por ato normativo, o particular não terá direito à indenização, o que pode acontecer no caso da servidão decorrer de contrato ou decisão judicial (PENTEADO, 2014, p. 284). Passagens de gasoduto e linhas elétricas são exemplos frisantes desse tipo de intervenção.

A requisição administrativa, por sua vez, está prevista no inciso XXV da Constituição da República, e tem por finalidade permitir ao Estado a utilização de um determinado bem através de solicitação prévia, nos casos de iminente perigo público. Em tempos de guerra - a requisição militar é regulamentada pelo Decreto-Lei ${ }^{\circ} 4.812 / 1942$, ainda vigente - pode servir à defesa do país no caso de localização estratégica do imóvel, por exemplo. A requisição civil, também prevista no $\S 3^{\circ}$ do art. 1228 do Código Civil, pode atender a outras finalidades, como os casos de calamidade pública, a exemplo de grandes enchentes e deslizamentos de terra. Em havendo danos é assegurada indenização ao proprietário, nunca prévia, como no caso da desapropriação.

Já na ocupação temporária, como o próprio termo indica, o Estado utiliza o imóvel do particular por um tempo determinado, podendo ensejar indenização de acordo com as peculiaridades do caso concreto. Hely Lopes Meirelles a define como "a utilização transitória, remunerada ou gratuita, de bens particulares pelo Poder Público, para a execução de obras, serviços ou atividades públicas ou de interesse público" (MEIRELLES, 1995, p. 538). Um exemplo típico é utilização de terrenos contíguos a obras públicas para guarda transitória de máquinas e equipamentos de serviço. Considera-se igualmente ocupação temporária, o uso de escolas e outros estabelecimentos privados por ocasião de eleições.

Poucas são as normas jurídicas que versam sobre o instituto da ocupação temporária, estando o mesmo expressamente previsto no art. 36 da Lei de Desapropriações (Decreto-Lei n 3365/1941), nos seguintes termos: “É permitida a ocupação temporária, que será indenizada, afinal, por ação própria, de terrenos não edificados, vizinhos às obras e necessários à sua realização. $\mathrm{O}$ expropriante prestará caução, quando exigida".

O tombamento limita o direito de propriedade para a preservação de um interesse histórico ou artístico incorporado a um imóvel determinado (PENTEADO, 2014, p. 284). Trata-se de uma restrição parcial, já que a propriedade permanece com o particular, que fica sujeito à fiscalização pelo órgão técnico competente e permanece com o dever de preservá-lo, necessitando de aprovação 
do órgão para eventuais reformas, mantidas sempre as características que ensejaram o tombamento. No caso da propriedade privada, pode ser realizado por intermédio de pedido efetuado pelo proprietário (voluntário) ou por iniciativa do poder público, ainda que em contrariedade à vontade do proprietário (compulsório). O instituto é regulamentado pelo Decreto-Lei $\mathrm{n}^{\circ}$ 25/1937.

As limitações administrativas em geral, que os administrativistas apontam não como gênero mas espécie de intervenção do Estado na propriedade, são as que mais se aproximam do ente federativo municipal. São imposições dirigidas a proprietários indeterminados, de natureza geral, gratuita e unilateral, que condicionam o exercício do direito de propriedade. São preceitos de ordem pública que derivam da supremacia do interesse público sobre o privado e não ensejam indenização. Podem emanar da lei ou de outros atos normativos de natureza administrativa e consistir em obrigação de fazer, como a limpeza de terreno, por exemplo, e de não fazer, como a obediência a limite de altura em determinada construção. Pode também obrigar o proprietário a tolerar determinada ação administrativa, como vistorias.

No que concerne à desapropriação, esta é, como já afirmado acima, a modalidade mais grave de intervenção do Estado na propriedade, já que subtrai do titular, de maneira compulsória, o domínio de determinado bem, cabendo ao proprietário uma indenização justa e prévia em dinheiro (arts. $5^{\circ}, \mathrm{XXIV}$, e 182 , $\S$ $3^{\circ}, \mathrm{CR}$ ), não sendo possível a este se insurgir contra o ato expropriatório (LÔBO, 2015, p. 171). No item a seguir serão tratadas as intervenções na propriedade em sua relação com o Município, identificando-se com maior precisão as hipóteses práticas.

\section{MOdos ESPECÍFICOS DE INTERVENÇÃo DO MUNICÍPIO NA PROPRIEDADE PRIVADA}

Com a finalidade de implementação das políticas públicas inerentes ao desenvolvimento urbano centrado no ideal de justiça social, tal como determinado pelo art. 182 da Constituição da República, foi editada, após mais de uma década da promulgação da Carta de 1988, a já mencionada Lei $\mathrm{n}^{\circ}$ 10.257/2001, o chamado Estatuto da Cidade. Este diploma legislativo, mais do que um sistema de normas de direito urbanístico, fornece instrumentos essenciais para as funções e atividades exercidas nas cidades, tanto no que concerne ao planejamento, quanto à execução, conduzindo também o poder público na ordenação e controle do solo urbano, em articulação com outros instrumentos normativos municipais, a exemplo do Plano Diretor, o qual, além de ordenador físico e territorial da cidade, nos diferentes usos decorrentes do zoneamento em diversas áreas - industrial, de preservação, de interesse social, entre outras - é 
também um mecanismo de administração e gestão construído a partir da pluralidade e necessidades existentes nas cidades (PRESTES, 2008, p. 36).

Nesse sentido, é bastante ampla a gama de medidas interventivas no âmbito municipal, assim como abundante é o conjunto de instrumentos normativos responsáveis por sua regulamentação.

Dessa forma, a partir dos dispositivos constitucionais aplicáveis às espécies e das normas gerais emanadas da União e dos Estados membros, dada a complexa teia de atribuição de competências aos entes federativos, cabe ao poder público de cada Município, seja o legislativo, seja o executivo, detalhar as medidas que contribuirão para o desenvolvimento e organização de seu respectivo território, levando-se sempre em consideração a unidade do sistema e os objetivos e princípios eleitos pelo Estado brasileiro para a consecução da justiça social, sendo certo que é na cidade que o exercício da dignidade de seus habitantes se concretiza e se apresenta com maior densidade.

A servidão administrativa pode ser instituída pelo Município, representando a forma mais comum a instalação de placa com o nome da rua em uma propriedade específica. Diversas outras hipóteses podem ser suscitadas, a exemplo da que foi instituída pelo Poder Executivo do Município do Recife para implantação de tubulação de esgoto sanitário (emissário) no âmbito do Projeto de Esgotamento Sanitário da Cidade do Recife, através do Decreto $\mathrm{n}^{\circ} 27.241$, de 24 de julho de $2013^{6}$.

A requisição administrativa da propriedade privada na modalidade militar, como visto no item anterior, é prerrogativa das forças armadas e será exercida mediante a edição de decreto do Poder Executivo Federal, nos termos do art. $7^{\circ}$ do Decreto-Lei n 4812/1942. Já a requisição administrativa civil pode ser levada a efeito pelo Município, através do Poder Executivo, o qual declarará por Decreto os casos de emergência ou calamidade pública, ensejando assim a requisição de bens. Hipótese frisante se encontra insculpida no inciso XIII, do art. 15, da Lei $n^{\circ}$ 8080/1990, que instituiu o Sistema Único de Saúde (SUS):

Art. 15. A União, os Estados, o Distrito Federal e os Municípios exercerão, em seu âmbito administrativo, as seguintes atribuições: $(\ldots$.

XIII - para atendimento de necessidades coletivas, urgentes e transitórias, decorrentes de situações de perigo iminente, de calamidade pública ou de irrupção de epidemias, a autoridade competente da esfera administrativa correspondente poderá

6 Disponível em https://leismunicipais.com.br/a1/pe/r/recife/decreto/2013/2725/27241/decreto-n27241-2013-declara-de-utilidade-publica-para-fins-de-instituicao-de-faixa-de-servidaoadministrativa-as-areas-que-especifica?q=servid\%E3o. Acesso em 28 jun.2019. 
requisitar bens e serviços, tanto de pessoas naturais como de jurídicas, sendo-lhes assegurada justa indenização;

O dispositivo acima transcrito autoriza o Município, dado seu dever e escopo de prestar assistência à saúde da população, a intervir nas entidades privadas que prestam serviços de saúde, nos casos nele especificados, com a finalidade de permitir e preservar a continuidade de tais serviços ou mesmo restabelece-los, podendo também para tanto requisitar bens.

Ao Município compete fazer uso da ocupação temporária, a qual atinge apenas a propriedade de bens imóveis, nos exatos termos do art. 36 do DecretoLei $n^{\circ} 3365 / 1941$, quando da expropriação pelo mesmo promovida, ainda que possa haver ocupação temporária também no caso de obras públicas não vinculadas a uma desapropriação.

Embora a competência para legislar sobre o tombamento de bens seja concorrente à União, aos Estados e ao Distrito Federal, na forma do disposto no inciso VII do art. 24 da Constituição da República, ao Município é permitida a sua execução, dado o comando contido no inciso IX do art. 30 do texto constitucional, que lhe outorga competência para promover a proteção do patrimônio históricocultural local, observada a legislação federal e a estadual, além da ação fiscalizadora desses entes.

As limitações administrativas, que podem alcançar tanto bens imóveis quanto móveis, representam a maior parte das intervenções no direito de propriedade a cargo do ente municipal. O planejamento e organização do espaço urbano impõem a implementação das políticas públicas que mais interferem na seara privada, dada a necessidade de se estabelecer como se dará o uso e a ocupação do solo na cidade, a distribuição espacial da população e das atividades econômicas em seu território, assim como o transporte e outros serviços públicos, além da infraestrutura de saneamento e abastecimento de água, entre inúmeras outras diretrizes. O crescimento ordenado do espaço urbano deve ser uma preocupação constante e a plenitude da função social da cidade depende das limitações administrativas.

Essas limitações podem se expressar através dos mais diversos atos normativos emanados do Poder Público municipal e nas mais distintas situações jurídicas, desde o estabelecimento de gabarito para edifícios em determinados bairros até o embargo de obras não licenciadas em andamento ou a demolição daquelas que, uma vez finalizadas, não obedeceram aos recuos necessários. As construções irregulares são uma constante nas cidades brasileiras, repositório maior da desigualdade social e dos problemas decorrentes das recorrentes crises financeiras. O Plano Diretor, a Lei de Uso e Ocupação do Solo e uma gama de instrumentos normativos compõem a legislação de regência das limitações administrativas. 
Antes de discorrer sobre a desapropriação, convém dar destaque ao Decreto ${ }^{\circ}$ 31671, de 10 de agosto de 2018, do Município do Recife, o qual vem buscando solucionar um sério problema que atinge a gestão da cidade e a segurança e bemestar dos cidadãos. Trata-se dos diversos imóveis abandonados por seus proprietários - em geral em péssimo estado de conservação - quando estes não possuam intenção de conservá-los em seu patrimônio e ditos bens não se encontrem na posse de outrem. Prevê-se a instauração de um procedimento administrativo pela Procuradoria Geral do Município, o qual uma vez instruído será encaminhado por notificação ao proprietário que terá prazo para impugná-lo. A parte pode impugnar a situação de abandono, reconhecendo, porém, o estado de deterioração do imóvel, quando promoverá as ações necessárias à sua recuperação. Comissão formada no âmbito da Procuradoria Geral do Município julgará o processo, cabendo recurso da respectiva decisão. Encerrado o procedimento administrativo, o Chefe do Executivo declarará o imóvel como bem abandonado e sujeito à arrecadação, nos termos do art. 1276 do Código Civil. E uma vez publicado o Termo de Declaração de Vacância e Arrecadação de Bem Imóvel Abandonado, a Procuradoria ajuizará ação visando à transferência do imóvel a sua titularidade, em três anos contados a partir da data da publicação ${ }^{7}$.

Quanto à expropriação de bens, além da modalidade ordinária ou clássica constante do Decreto-Lei $n^{\circ} 3365 / 1941$, compete ao Município promover outras espécies, previstas na Constituição da República e em leis especiais.

A desapropriação clássica tem seu fundamento no inciso XXIV do art. $5^{\circ}$ da Constituição e é regulamentada pelo mencionado Decreto-Lei n 3365/1941 - Lei de Desapropriações. Os requisitos constitucionais para as expropriações regidas pelo referido diploma legal são os de que a expropriação se dê em razão de utilidade pública e mediante justa e prévia indenização. O mesmo ocorre com o requisito do interesse social, cuja regulamentação se encontra na Lei n 4132/1962, a esta aplicadas também as disposições do Decreto-Lei n ${ }^{\circ} 3365 / 1941$.

Uma modalidade extraordinária de desapropriação e que possui caráter punitivo se insere na ambiência da política de desenvolvimento urbano e pode ser promovida pelo Município, desde que, mediante lei específica para área incluída no Plano Diretor, seja exigido, nos termos da lei federal, do proprietário do solo urbano não edificado, subutilizado ou não utilizado, que promova seu adequado aproveitamento. Trata-se de uma sanção para os casos do não condicionamento da propriedade a sua função social. A indenização, neste caso, não é prévia e será realizada mediante títulos da dívida pública.

Situação mais grave está estampada na modalidade extraordinária prevista no art. 243 da Constituição da República, o qual autoriza a desapropriação de

\footnotetext{
7 Disponível em https://leismunicipais.com.br/a1/pe/r/recife/decreto/2018/3167/31671/decreto-n31671-2018-estabelece-no-ambito-do-poder-executivo-municipal-o-procedimento-

administrativo-destinado-a-arrecadacao-de-imoveis-urbanos-por-abandono. Acesso em 28 jun.2019.
} 
propriedades rurais e urbanas onde foram localizadas culturas ilegais de plantas psicotrópicas ou a exploração de trabalho escravo, as quais serão destinadas a programas de habitação popular. Esta modalidade não prevê indenização ao proprietário, sendo certo que, de acordo com o parágrafo único do mencionado artigo, todo e qualquer bem apreendido sob as circunstâncias prevista no caput será confiscado. Embora possa atingir imóveis urbanos, a desapropriação confiscatória será promovida pela União, como determina a lei que a regulamenta (Lei $\left.n^{\circ} 8.257 / 1991\right)$.

\section{CONCLUSÃo}

A organização do Estado brasileiro, com o advento da Constituição da República de 1988, além de normas programáticas e estruturais, trouxe meios efetivos para a concreção de uma política urbana condizente com a opção do constituinte pela justiça social como fundamento e objetivo, pelo que a função administrativa do poder público se afigura na forma de atividades dirigidas por políticas públicas que visam a realização dos direitos sociais (CASIMIRO, 2008, p. $55)$.

Nessa toada, o Município, que antes exercia um papel coadjuvante na implementação das referidas políticas públicas, assumiu o protagonismo na execução das diretrizes que visam a ordenação urbana e o desenvolvimento das cidades, calcadas ditas linhas nos direitos e garantias fundamentais do cidadão, o que possibilita proporcionar-lhe moradia digna e acesso a bens e serviços, entre outros.

Na cidade é que desaguam os problemas, as questões mais próximas ao cidadão e que exigem medidas efetivas e diretas por parte do poder público.

E se o constitucionalismo do século XX introduziu em alguns Estados a busca pela justiça social em paralelo a uma ordem econômica capitalista, o que no Brasil, como dito, foi introduzido pela Constituição de 1934, o ordenamento estabelecido em 1988, além de reafirmar o conteúdo da propriedade condicionada a uma função social, ampliou e adequou este vetor às necessidades coletivas, implementando também uma função social à cidade. Para promovê-la, a Constituição direcionou as ações públicas a serem desenvolvidas à política urbana capitulada no título da ordem econômica (arts. 182 e 183, CR).

Assim é que ao Município é dada a mais ampla e importante gama de medidas interventivas e limitadoras do exercício do direito de propriedade.

Nesse sentido, o presente trabalho procurou demonstrar a forte interlocução existente entre o direito civil constitucional e o direito administrativo nas questões que envolvem o direito de propriedade, apresentando um panorama de como se efetiva a intervenção do Estado na propriedade privada, com ênfase para o papel do ente municipal nesta complexa rede de interesses e situações jurídicas. 


\section{REFERÊNCIAS}

ANDRADE, Gustavo Henrique Baptista. O direito de herança e a liberdade de testar: um estudo comparado entre os sistemas jurídicos brasileiro e inglês. Belo Horizonte: Fórum, 2019.

BONAVIDES, Paulo. Curso de direito constitucional. São Paulo: Malheiros, 2004.

CASIMIRO, Lígia Maria Silva Melo de. Uma análise sobre o capítulo da política urbana na Constituição de 1988. Revista Magister de direito ambiental e urbanístico. Porto Alegre: Magister, vol. 19, ago./set., p. 40-60, 2008.

FACHIN, Luiz Edson. A construção do direito privado contemporâneo na experiência crítico-doutrinária brasileira a partir do catálogo mínimo para o direito civil-constitucional no Brasil. In: TEPEDINO, Gustavo. Direito civil contemporâneo. Novos problemas à luz da legalidade constitucional. São Paulo: Atlas, 2008, p. 12-17.

GOMES, Orlando. Direitos reais. Rio de Janeiro: Forense, 1988.

ISMAIL FILHO, Salomão. Uma definição de interesse público e a priorização de direitos fundamentais. 2016. Disponível em: <https://www.conjur.com.br/2016mar-28/mp-debate-interesse-publico-priorizacao-direitos-fundamentais>. Acesso em: 27 jun. 2019.

LÔBO, Paulo. Direito civil. Parte geral. São Paulo: Saraiva, 2019.

LÔBO, Paulo. Direito civil. Coisas. São Paulo: Saraiva, 2015.

LÔBO, Paulo. Direito civil. Parte geral. São Paulo: Saraiva, 2009.

MEIRELLES, Hely Lopes. Direito administrativo brasileiro. São Paulo: Malheiros, 1995.

PENTEADO, Luciano de Camargo. Direito das coisas. São Paulo: RT, 2014.

PERLINGIERI, Pietro. Perfis do direito civil. Introdução ao direito civil constitucional. Renovar, 2002. 
PRESTES, Vanêsca Buzelato. A função social da propriedade nas cidades: limitações administrativas ao conteúdo da propriedade. Revista Magister de direito ambiental e urbanístico. Porto Alegre: Magister, vol. 18, jun.jjul., 2008.

RODOTÀ, Stefano. Il terrible diritto. Studi sulla proprietà private e I beni comuni. Bologna: Mulino, 2013.

SILVA, José Afonso da. Curso de direito constitucional positivo. São Paulo: Malheiros, 2012.

TEPEDINO, Gustavo. O princípio da função social no direito civil contemporâneo. In: NEVES, Thiago Ferreira Cardoso (Coord.). Direito e justiça social. Por uma sociedade mais justa, livre e solidária. Estudos em homenagem ao Professor Sylvio Capanema de Souza. São Paulo: Atlas, 2013.

TEPEDINO, Gustavo. Premissas metodológicas para a constitucionalização do direito civil. In: Temas de direito civil. Rio de Janeiro: Renovar, 2004.

TOLENTINO, Fernando Lage; THIBAU, Vinícius Lott. Federalismo brasileiro e repartição de competências em matéria urbanística. In: COSTA, Beatriz Souza; REIS, Émilien Vilas Boas; RIOS, Mariza; CARVALHO, Newton Teixeira. Direitos fundamentais aplicados à cidade. Belo Horizonte: Del Rey, 2015.

VARELA, Laura Beck; LUDWIG, Marcos de Campos. Da propriedade às propriedades: função social e reconstrução de um direito. In: MARTINS-COSTA, Judith (Org.). A reconstrução do direito privado. São Paulo: RT, 2002. 